\title{
The Conflation of Participatory Budgeting and Public-Private Partnerships in Porto Alegre, Brazil: The Construction of a Working-Class Mall for Street Hawkers
}

\author{
Ana Paula Pimentel Walker \\ Department of Urban and Regional Planning, University of Michigan, Ann Arbor, MI 48109, USA \\ Corresponding author: Ana Paula Pimentel Walker; e-mail: appiment@umich.edu
}

This article addresses the political transition of Porto Alegre's Participatory Budget from a mechanism of restraining and managing some of the harshest manifestations of neoliberal urbanization to a promoter of profit-driven urban development. The most emblematic instance of the transition is the public-private partnership for the construction and management by a developer of a marketplace to relocate downtown street hawkers to an enclosed building. The article describes not only how the mayor's office was able to approve, as part of the downtown revitalization project, the relocation of street hawkers into a working-class popular shopping mall but also how the executive branch succeeded in transforming a public-private partnership into an elected participatory budget demand. Furthermore, I demonstrate how neoliberal programs of public-private partnerships undermine more redistributive participatory practices, such as the participatory budget, by combining their mechanisms with the older practices rather than eliminating the rival planning tool. This article provides an analysis of local class interests and strategies regarding the issue of street hawking in Porto Alegre by contrasting models of participatory planning. I argue that social classes with an investment in the urban question are key actors in developing hybrid models of neoliberal urbanization.

Keywords Participatory Budget; City planning; Neoliberalism; Street hawkers; Informality

How vulnerable are participatory institutions to partisan politics and market forces? What are the circumstances under which the redistributive achievements of counterhegemonic forms of urbanization and globalization, such as the Participatory Budget (PB) of Porto Alegre, are reversible? In Brazil, democratization coincided with neoliberalization, deeply changing the production of urban space in sometimes paradoxical ways (Caldeira \& Holston, 2005, p. 409). Urban social movements were highly influential in placing urban reform at the center of constitutional debates (Rolnik, 2011). However, Brazil's redemocratization in the 1980s effectively spelled the end of developmentalist and modernist models of urbanization and planning (Caldeira \& Holston, 2005); consequently, more attention was then paid to the urban poor. For instance, housing became a fundamental social right. New land-use laws guaranteed the rights of some squatters, special subdivision standards for illegal settlements, and redistributive mechanisms of taxation for urban properties. Urban social movements articulated a new type of rights to the city. These rights included claims on housing, transportation, infrastructure, culture, and safety, to be achieved through participatory urban policies such as participatory master plan councils and the PB (Rolnik, 2011). ${ }^{1}$ 
Brazil's 2001 Federal City Statute made participatory master plans mandatory for municipalities with more than 20 thousand inhabitants. However, Porto Alegre's version of the PB, as it is internationally known, remained largely voluntary. The city statute requires only one public hearing before final municipal budgetary approval. The PB not only shifts the municipality's revenue allocation powers from the city council to public assemblies attended by residents in each one of the city's 17 districts, it also serves as an inspiration for hundreds of other Brazilian cities. Moreover, the Brazilian right to the city movement encouraged the creation of the Right to the City Alliance in other countries, including the United States, which has active chapters in New York City and Los Angeles (Harvey, 2012).

Other scholars (e.g., Heller, 2001; Santos, 2005) have sought to understand the success of the PB as a means of redistributing resources to the urban poor. This article, however, addresses the circumstances that led to the transition of Porto Alegre's PB from a means of restraining and managing some of the harshest injustices of neoliberal urbanization to a promoter of profit-driven urban development. My goal is to evaluate the political and economic conditions of the transition rather than to provide a full account of its effects. ${ }^{2}$ As the evidence in this article demonstrates, the transition is complex; simplistic explanations, such as the death of the $\mathrm{PB}$, are insufficient. To illustrate the transition, I examine a public-private partnership to construct and manage a new enclosed marketplace downtown, which was built to house relocated street hawkers.

Notably, Brazil's movement for both urban reform and a right to the city did not address informal trade; for instance, the Federal City Statute does not mention it. Consequently, street hawkers from around the country continue to organize in their own labor unions at the local level. In Porto Alegre, street hawkers inserted themselves at the center of the urban question at a moment of important political transition in participatory budgeting and planning in this historical city.

By focusing on the transition of the $\mathrm{PB}$ of Porto Alegre from a municipal program of redistributive justice to a neoliberal program of business development, this article elucidates the contradictory tools of city governance that have been shaping Latin American urban development since structural adjustment and democratization's third wave. I focus on urban governance, especially participatory and deliberative city planning, so as to tease out assertions about the "perverse confluence" (Dagnino, 2003, p. 7) of leftist and neoliberal programs of participatory planning and development. Most of these claims imply that urban social movements and professionals, including architects, planners, and lawyers, have naively promoted participatory planning, as they failed to foresee that such planning effectively serves as a tool for structural adjustment and neocolonial urban development. By analyzing Porto Alegre's political transition from four administrative terms of the Workers' Party (Partido dos Trabalhadores) to a center-right coalition government, this article demonstrates that simply depicting recent change as a confluence of participatory planning and neoliberalism does not accurately convey why the PB lost its power as a market-restraining tool.

To expound on the ideological, policy, and symbolic shifts in the PB throughout its 22-year history, I select the example of the approval and construction, through a public-private partnership, of the Camelódromo, a popular shopping center housing more than 800 street hawker stalls. The name "Camelódromo" comes from camelô (camel) and references the labor practices of semisedentary street vendors who carry their merchandise and tents on their backs. "Camelódromo" is the pejorative name used by the street hawkers themselves to humorously acknowledge the lowly labor category they occupy in society. The municipality prefers the name "Popular Shopping Center," because the word popular in Brazilian Portuguese denotes the preferences of the humble people and not those of local 
elites. Finally, the developer, Verdicon, elected to call the new marketplace the Wharfs Shopping in an attempt to represent the changing lifestyles, products, and clients its management promised to bring to former street hawkers.

This article is based on my dissertation fieldwork, which took place from July 2009 through March 2011. ${ }^{3}$ Methodologies included participant observation of PB meetings, archival research of PB meeting minutes, transcriptions of meetings of the Council of the Participatory Budget (COP) for the past 15 years, and collection of oral histories. With these data, I could document the evolution of the $\mathrm{PB}$, compare the expenditure and capital investments budget before and after the Workers' Party government, and compare longitudinally the relationship between political party ideology and participatory budgeting and planning. I attended and tape recorded weekly meetings of both the Downtown Forum of Delegates of the Participatory Budget (FROP) and the COP. I also attended several meetings of the formal and informal associations involved in the $\mathrm{PB}$ at squatter settlements and public housing projects in downtown Porto Alegre. I conducted interviews with current delegates and councilors and a sociodemographic survey of the downtown FROP and COP. I conducted multiple interviews with Alberto and the delegates to the Thematic Forum on Economic Development, Taxation, Tourism, and Labor representing the Plaza XV camelôs. I also visited the Camelódromo on several occasions to chat, shop, and observe the complaints about economic hardship and lack of clientele voiced at the downtown PB meetings.

In this article, I describe how the mayor's office was able to approve, as part of the downtown revitalization project, the relocation of street hawkers into a popular working-class shopping mall. I also address how the executive branch succeeded in transforming a public-private partnership into a PB demand. Furthermore, I demonstrate how neoliberal programs of public-private partnerships undermine the more redistributive and participatory practices of the PB by combining their mechanisms with older practices rather than eliminating the rival planning tool.

\section{Latin American cities in the aftermath of structural adjustment}

Neoliberal restructuring projects have produced uneven and heterogeneous patterns of development that significantly affect the political economy of cities, nations, and world regions (Brenner, Peck, \& Theodore, 2010). In Latin America, the role of the state during and after the structural adjustment policies of the 1980s and 1990s has been to implement the economic and institutional changes required to promote privatization and free trade. However, the neoliberalization of Latin American political economies has not been a monolithic process, because mixed versions of neoliberal states exist in the region (Perreault \& Martin, 2005). States, in combination with development agencies such as the World Bank Group, remain key architects of ideologies of either market democracy in countries such as Chile, Colombia, and Argentina or neodevelopmentalism in Bolivia and Venezuela (Goodale \& Postero, 2013).

In Brazil, trade liberalization and privatization of state-owned and mixed enterprises have been accompanied by moderate increases in social spending on health and education and modest cash assistance for poor families. These social programs aimed to address the unemployment caused by the closing of factories associated with the abandonment of import substitution industrialization policies (Green, 2003). The urban impact of deindustrialization on Rio de Janeiro, Buenos Aires, Mexico City, and other metropolitan centers contributed to sharply declining growth rates (Portes \& Roberts, 2005, p. 51). In most Latin American countries, declining formal employment resulted in growing informal employment (Portes \& Roberts, 2005, p. 57). In Brazil, some 55\% of the workforce is employed in the 
informal sector, and within that sector, 7\% work as street hawkers. In Porto Alegre, street hawkers compose $7 \%$ of the economically active population (Roever, 2010, p. 233). Thus the predictions of structural adjustment advocates that free markets would increase formal employment proved largely unfounded for Latin American cities (Portes \& Roberts, 2005, p. 58).

Public-private partnerships represent the cornerstone of neoliberal urban governance (Hackworth, 2007, p. 61) because they characterize the changing role of municipal governments in post-Fordist capitalism: from managers in the delivery of public works and services to entrepreneurs who effectively seize opportunities for urban economic development (Harvey, 1989, p. 7). Public-private partnerships have had a great impact on urban redevelopment projects in both developing and developed countries. For instance, Porto Alegre's downtown redevelopment project is financed in large part via public-private partnerships, and the construction of the Popular Shopping Center is one of them.

The transition from strong government regulation to a free-market economy and from military regimes to electoral democracy continued to influence political parties' ideology of participatory planning in Brazil until very recently. For instance, during the four Workers' Party administrations in Porto Alegre, social movements, politicians, and planners attempted to manage profit-led neoliberal urbanization. When the French multinational Carrefour wanted to create a megasupermarket, Porto Alegre created a committee to write an impact report. The report's economic development component estimated that for every Carrefour job created, six jobs would be lost, mostly in nearby small retail shops. Based partly on such findings, the Impact Report Committee successfully negotiated a mitigation package for local economic development; among other compensations, it required Carrefour to buy from local producers and hire local businesses (Goldsmith \& Vainer, 2001; Tendler, 2000).

Decentralization was another institutional reform recommended by the World Bank, International Monetary Fund, and other lending and development institutions as part of structural adjustment. In many developing countries, decentralization was the least contested structural adjustment, as social movements were eager to exercise more control over local politics (e.g., Elinoff, 2012). However, in most cases, neoliberal decentralization increased cities' fiscal responsibilities without increasing their revenues (Beard, Miraftab, \& Silver, 2008; Perreault \& Martin, 2005). In Latin America, the promotion of citizen participation in local government has accompanied much of this fiscal and administrative decentralization (Campbell, 2003; Kohl, 2003). In Brazil, decentralization is known as municipalization, because the federal government directly transferred power to municipalities (Dickovick, 2007). The PB emerged amid this larger context of decentralization and public participation. Although the innovations were considered bottom-up, international development agencies quickly recognized the program's merits. The PB represented a good advertisement for important structural adjustment policies such as decentralization and fiscal reform, as the next section demonstrates.

Here I adopt a conceptual approach that balances an analysis of the neoliberalized economic system, of which the Camelódromo is both a product and an agent, with the local context of class interests, alliances, and disputes that led to the public-private partnership. I argue that social classes with an investment in the urban question are key actors in developing hybrid models of neoliberal urbanization; therefore their coalitions and disputes deserve our attention. In this article, I address street hawkers as part of the working class and investigate their political actions and alliances as the most affected stakeholders of this public-private partnership. Moreover, I focus on the issues street vendors raised at the $\mathrm{PB}$ meetings, the outcomes of $\mathrm{PB}$ deliberations, and the ongoing changes in participatory planning rather than on the lives of the street hawkers per se. ${ }^{4}$ 


\section{The Participatory Budget process and cycle}

Porto Alegre is the capital of Rio Grande do Sul, which boasts Brazil's fourth-largest metropolitan area of 4.4 million inhabitants. In 1989, when the Workers' Party took power in the city for the first time, activists pushed for broad changes in city planning, and the municipal government began to implement the $\mathrm{PB}$. The $\mathrm{PB}$ transfers decision making regarding the allocation of municipal capital investments from the Porto Alegre City Council to the general public gathered in public assemblies. The PB became the symbol of the Workers' Party's administration and the signature project of Mayor Olívio Dutra, who envisioned and implemented it.

When the PB first started in 1989, the experiment was not successful because the available resources for investment were insignificant. The Workers' Party implemented an efficient fiscal reform, which increased capital investments within the municipal budget from 2\% in 1989 to 20\% in 1994 (Baiocchi, 2003, p. 50). This augmented investment for potential allocation in poor neighborhoods spurred increased public participation by the city's less affluent residents. About half of the PB attendees at the yearly assemblies are poor, earning on average a little above the minimum wage (Fedozzi, Adriana, Carlos, Macedo, \& Valeria, 2009).

Since the PB implementation, members of social movements, nongovernmental organizations (NGOs), and neighborhood associations have mobilized nearly $8 \%$ of the city's population to participate in public debates and cast direct votes on the use of municipal resources. ${ }^{5}$ According to several scholars (Abers, 1998; Fedozzi, 2001), the PB reduces opportunities for clientelism between city council members and residents of squatter settlements because the former can no longer discretionally allocate public works in exchange for political support and votes.

The $\mathrm{PB}$ entails three instances of public participation, combining elements of direct and representative democracy (e.g., Lüchmann, 2008): the COP, the FROP, and the Regional and Thematic Assemblies (Figure 1). The annual Regional and Thematic Assemblies constitute the only instance of direct citizen participation. The PB divided Porto Alegre into 17 sociogeographic regions and six thematic forums, each of which holds a yearly assembly. In the assembly, the mayor renders an account of the prior budget, and residents cast their votes to select the issues to be prioritized in the upcoming budgetary year; they also elect two representatives to act as councilors at the COP. The thematic forums are Urban Mobility; Economic Development, Taxation, Tourism, and Labor; Education, Sports, and Leisure; Culture; Health and Social Welfare; and Housing and Urban Development. Individuals can attend and vote at all yearly assemblies of the thematic forums. However, they can cast their ballot only at the annual assembly of the district in which they reside.

Until 1994, the PB took place primarily at the district level, with most participants belonging to neighborhood associations. The participation of other entities, such as unions and women's movements, had been minimal. To increase participation of these entities in the deliberations of the city budget, the government established the thematic forums. There was some concern that the PB had become too narrowly focused on the immediate needs for public works and services to low-income neighborhoods; some thought it lacked a vision for the city as an integrated entity. Except for a few cases like the Thematic Forum on Culture, which attracted some sectors of Porto Alegre's black movement, the thematic forums have not really fulfilled their overall mission to reflect holistically on the city and appeal to civil society organizations.

However, squatters' neighborhood and street hawker associations often successfully brought their concerns to a vote at the thematic forums. For instance, street hawkers organized both at the district 


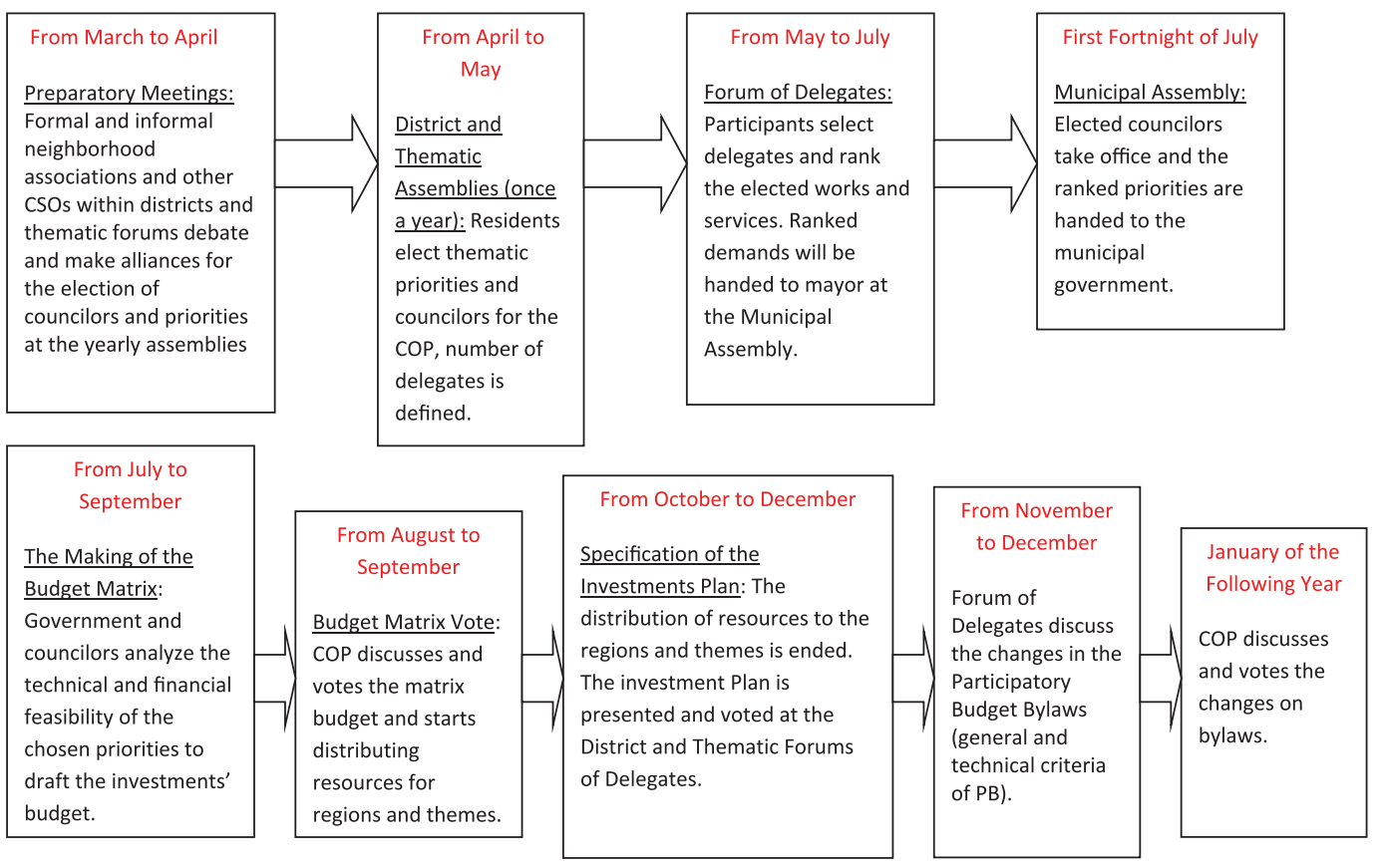

Figure 1 Cycle of the Participatory Budget.

level and at the Thematic Forum for Economic Development, Taxation, Tourism, and Labor. Alberto, representative of the Plaza XV registered camelôs, has been a councilor of the PB five times since 2007 for the Thematic Forum for Economic Development, Taxation, Tourism, and Labor. Some street hawkers' associations maintain strong alliances with the associations that represent the neighborhoods where they live and work. Such ties allow street sellers to communicate their demands through the district, even though some hawkers prefer to mobilize their demands through the thematic forum.

Jefferson, representing the unregistered stallholders of Rua da Praia, has served as a councilor of the downtown region of the PB seven times since 2005. The Association of Unregistered Stallholders of Rua da Praia had the second-largest representation at the downtown FROP. The association brought 59 stallholders to the 2010 downtown annual assembly, which enabled the group to nominate six district delegates. For every 10 participants that any formal or informal association brings to the yearly assembly, the organization can appoint one delegate to the FROP.

The FROP meets weekly, biweekly, or monthly, according to the bylaws of each district and thematic forum. Prior to each year's district and thematic assemblies, delegates and independent citizens gather in the appropriate FROP to debate the priorities that they will consider in the yearly assembly. These priorities can range from the construction of public housing and street paving to the development of schools, health clinics, and cultural centers. After the priorities are voted on at the yearly assemblies, delegates return to the FROP to rank the specific demands from their region for consistency with the priorities selected at the yearly assembly. For instance, if the priority elected at the yearly assembly is street paving, then at the subsequent FROP meetings, delegates will deliberate on which streets will be paved first, including the exact meters of pavement.

The COP comprises two councilors and two alternates from each district and thematic forum. COP duties include the approval of municipal capital investments plans, PB bylaws, public works monitoring, 
and meetings with municipal officials to secure greater resources for public works and services and expedite their implementation.

Resources for the selected priorities of the annual assemblies are derived from the capital investment portion of the city budget. Brazilian municipalities have fixed, often constitutionally required, expenses. The first portion of the city budget is allocated by the municipal budgetary cabinet for these set expenses. The capital investment budget composes the budget's second component and is allocated according to PB-elected priorities. Both portions of the budget can fluctuate annually, depending on factors such as changing debt obligations. In the early 2000s, when Brazil underwent moderate fiscal recentralization, tax transfers to municipalities declined. In addition, municipal bond funding declined because of the 2002 South American economic crisis and anxieties about Brazil's possible default on foreign debt. Thus the city of Porto Alegre went from a budget surplus of $4 \%$ in 2001 to a deficit of $4 \%$ in 2004. Such factors contributed to a dramatic decline in the implementation of elected PB demands. The delayed demands caused great discontent and may have contributed to the 2004 electoral defeat of the Workers' Party.

PB councilors have traditionally questioned the allocation of resources for the budget's fixed expenses. For instance, verbatim transcriptions of COP meetings during the Workers' Party administrations show that councilors primarily questioned the fixed expenses that funded advertisements for municipal services and programs, some of which they viewed as political propaganda. As a result of the debates between the municipality and the PB councilors, resources often reverted from the government propaganda (e.g., informative pamphlets and radio and television announcements) to the priorities selected at the yearly assemblies. Simultaneously, councilors ended up convinced by municipal officials that some government agendas benefited the public good and were not necessarily a tool for partisan politics. In contrast, at the extraordinary meetings I attended in 2009 and 2010, councilors, eager to seal the budget matrix between the budgetary cabinet and the COP, did not question or even review the budget's expenditures. Instead, councilors simply asked municipal officials to allocate more resources to the budget's capital investments. The new municipal government has been conceding an extra R \$500 million (US\$294 million) to each of the 17 districts. ${ }^{6}$ Such concessions have been called "amendments" to the capital investment budget. The budgetary amendments are controversial because councilors and city planners question the co-optative nature of the amendments, with some councilors expressing mixed feelings when making their requests.

\section{Bureaucratic, political, and ideological shifts in the Participatory Budget of Porto Alegre}

The PB transferred resources from rich to poor neighborhoods (Marquetti, 2003). The less affluent regions received greater amounts of per capita investment and greater numbers of public works per thousand inhabitants between 1989 and 2000 than did middle-class neighborhoods. Moreover, illegal settlement areas also received greater per capita investments (Marquetti, 2003, p. 143). Slum-upgrading projects, sanitation, and health clinics spread to the city's outskirts in response to demands chosen by the poor, especially slum dwellers (Pimentel Walker, 2013a). The social nature of urban space in Brazil is fundamental in shaping social class dynamics (Santos, 2007). The redistribution in the PB was a step toward urban spatial justice.

For Edward Soja (2010), spatial justice not only entails unmasking the continuities of urban capitalism; it also fosters new imaginaries to facilitate the construction of new spaces of resistance based on hybrid coalitions of race, gender, and geography. For David Harvey (1989), territorial redistributive 
justice involves combating the causes of urban spatial inequalities, which he views as the social relations of production that generate a specific capitalist geography of spatial inequality. The PB never really fulfilled the criteria of Harvey's or Soja's concepts of spatial justice. It neither unmasked capitalist relations of production, nor did it create long-term hybrid coalitions in Porto Alegre. However, the PB did unveil class-based disputes over urban land occupancy. Urban squatters and informal traders came to meet with those who opposed their presence in the city center. This face-to-face confrontation was productive in targeting and strategizing protest, but the new municipal government opposes making local class disputes so highly visible.

The fact that the PB increased the amount of investment on housing and infrastructure in the city's outskirts was not widely opposed by Porto Alegre's upper and middle classes, as they already live and work in areas with highly capitalized infrastructure. In effect, their lifestyle remained unthreatened by efforts to help the poor who lived far away. Across Latin America, wealthy families live primarily in areas that expand outward from the historical city center, whereas the poor tend to inhabit the urban periphery (Feitosa, Camara, Monteiro, Koschitzki, \& Silva, 2007). The PB's most controversial aspects for middleand upper-class residents were Mayor Olivio Dutra's initiatives (1989-1992) and the backing of elected budgetary demands promoting better living and working conditions for the squatters and street hawkers who occupied valuable land at the city center. For instance, a PB demand for tenure security and slum upgrading for land occupied by informal garbage collectors and recyclers was particularly emblematic of a class conflict that pitted poor locals on one side against downtown businesses and middle-class residents on the other.

The demand generated international repercussions. A 1998 article by Bernard Cassen in Le Monde Diplomatique reports the radical transformations in local government:

The developers had their greedy eyes on the vila Planetário, a collection of shacks inhabited by scavengers occupying a prime site in the middle of town. All they had to do was send in the dogs and bulldozers as usual, to clear the way for the construction of high-class flats or offices. The PB enabled the inhabitants to be rehoused in the same place, in permanent dwellings. The vila is now the Jardim Planetário. (Cassen, 1998)

The oral histories I collected from some of the first PB delegates and councilors also allude to the event at which Mayor Dutra formed a human chain with Vila Planetário's poor to prevent police enforcement of a court eviction order, which was later revoked. As a result, some PB demands encountered resistance from powerful sectors of Porto Alegre society as well as from some middle-class citizens who disapproved of the poor's right to inhabit downtown.

An important item of Dutra's campaign platform was to regularize and formalize Porto Alegre's downtown street hawkers working at Plaza XV (Pinheiro Machado, 2004). During his time in office, Olívio Dutra granted more than 400 permits for street hawkers to work legally at Plaza XV. However, the number of unregulated street hawkers working in the larger downtown district grew to 1,800; for the entire city of Porto Alegre, the number was seven thousand by 2003 (Camarano \& Fraga, 2003). Among these licensed Plaza XV street hawkers was Alberto, who later became a PB councilor representing the Thematic Forum of Economic Development, Taxation, Tourism, and Labor. Alberto was an important protagonist in the controversial implementation of the Camelódromo project. 
Although three subsequent Workers' Party administrations continued PB-approved investments for slum upgrading in the urban periphery, they simultaneously deemphasized the right of informal residents and workers to occupy valuable city land. The more centrist administration of Tarso Genro-João Verle (2001 -2004), the Workers' Party's last elected mayor, did not consistently regulate local street hawkers. As the number of downtown street hawkers grew significantly, numerous complaints from the Porto Alegre Chamber of Commerce were registered. One of the new and unregulated camelôs was Jefferson, who, in 2001, created an association for the nonregistered stallholders of Rua da Praia. Because they represented different sets of interests, Jefferson and Alberto developed an antagonistic relationship.

Rival political parties in Porto Alegre severely criticized the Workers' Party administration almost from the start. However, these critics failed to predict the PB's success and did not effectively organize against it until the process was fully consolidated and had gained international visibility (Goldfrank, 2003, pp. 40-43). By the late 1990s, opposing center-right political parties tried unsuccessfully to question the PB's legality and publicly discredit its merits. ${ }^{7}$ These attempts were ineffective, in part because public opinion sided with the PB. A 2004 random opinion poll revealed that the majority of Porto Alegrenses supported the PB and would not vote for mayoral candidates who opposed it (Baiocchi, 2005). Public opinion favorable to the PB exerted palpable power in urban politics and economic development. The PB was legitimized in the eyes of both its Porto Alegre citizens and various multilateral development agencies. At a deeper level, recent research demonstrates that broad participation in decision making increases the level of satisfaction with development projects (Isham \& Kakhonen, 2003). Opposing political parties soon realized that their antiparticipatory planning ideologies lagged behind their class interests. Thus they began searching out planners, politicians, scholars, and partnerships who could develop a more politically palatable version of participatory planning and development.

By the fourth Workers' Party mandate (2001-2004), the opposition changed strategies and reframed the PB's merits as both a people's victory and an invention of the Porto Alegrenses. A coalition consisting of five center-right political parties called "A Better City, a Better Future" formed, with the 2004 mayoral campaign slogan of "Preserving Achievements, Building Change." The successful campaign promised to preserve the $\mathrm{PB}$ and create new forms of citizen participation (Baiocchi, 2005, pp. 158-159). As soon as Mayor Jose Fogaça took office, he inaugurated a new municipal secretariat called the Local Solidarity Governance (LSG), which downgraded the PB to a government program of equal status with other lesser-known participatory enterprises. With this bureaucratic reform, the COP became subordinate to the secretary of LSG, losing its former direct connection to the mayor's office.

The workings and philosophy of the LSG are explained in a DVD that promotes adherence to the new program. The DVD, made by the Prefeitura (the executive branch of the municipal administration) in collaboration with UNESCO, was shown at citizen training meetings to new and longtime community leaders. The UNESCO collaboration was fundamental to the program's legitimization. At the PB meetings, I often heard delegates and councilors refer to Porto Alegre as the world capital of participatory democracy. The PB's international recognition by the United Nations and the World Bank, as well as ongoing visits from foreign scholars and NGO workers, contributed to PB participants' sense that their political engagement was historic. ${ }^{8}$ Therefore the LSG program needed a partnership with an international organization with UNESCO's standing to enhance its legitimacy in the eyes of PB delegates and councilors. The following excerpt from the DVD reveals the ideology of participatory democracy:

The LSG does not aim to replace existing programs; it is here to complement them. This way you, the Porto Alegre citizen, can take a more proactive attitude towards your community. Being a citizen entails not only 
rights but also responsibilities. The government budget, in other words, the government's revenues, are still very important. In Porto Alegre, decision making on the allocation of public resources takes place through the PB's election of priorities. The PB is an achievement that has been fully integrated into the everyday life of communities in Porto Alegre.... However, not everything depends on the government; in addition to the government, the NGOs, the businesses, the communities, and the citizens also have to contribute by analyzing, discussing, and defining actions to promote development and inclusion in each community. (Prefeitura de Porto Alegre \& UNESCO, 2006)

The head of the LSG secretariat explained at PB meetings that it is financially unfeasible to expect that current public budget resources can address all urban problems related to poverty, substandard housing, and underemployment. However, some government officials maintain that with private-sector funding and citizen participation, the municipality can facilitate the implementation of projects that cannot be fully financed by the government. In this context, public-private partnerships such as the Camelódromo have emerged as important achievements of the LSG.

The LSG initiative came to symbolize the "A Better City, a Better Future" coalition. Mayor Fogaça's signature project became the construction of the Popular Shopping Center, the Camelódromo. However, for the project to gain acceptance, it could not be publicized only as a public-private partnership but instead required, at the very minimum, the camelôs' approval as well as the PB's involvement. Such legitimization would help realize the campaign promise of Preserving Achievements and Building Change. Street hawker Jefferson, then councilor of the PB's downtown region, made this political maneuver possible primarily through backstage political bargaining and public rhetoric.

\section{Camelódromo: Public-private partnership and Participatory Budget demand}

The political world, so often grim and disagreeable, is best tolerated by looking first for its absurdity, and then for its irony. (Bailey, 2001, p. xiii)

When the head of the municipal Secretariat for Economic Development contacted Alberto about the Camelódromo project (the public-private partnership), Alberto refused to relocate his operations to the proposed Popular Shopping Center, arguing that sales were booming at the Camelódromo of Plaza XV (the Camelódromo regularized in 1989 by Mayor Dutra). Alberto did not oppose building an additional Camelódromo in the streets per se, but rather disagreed with the idea of closing down the Plaza XV stalls. He was afraid that the clients would not follow them to the new location some three blocks away atop the bus corridor. Alberto held an excellent bargaining position because he had a permit to work at Plaza XV. He portrays himself as a small business leader with a vision for the future of his trade association. However, at the time, Alberto was not yet politically active in the PB, although he was as an experienced street hawker and a source of guidance for new ones. Given these circumstances, the head of the Secretariat for Economic Development focused all his efforts on Jefferson, the leader of the Stallholders of Rua da Praia. Jefferson had a revocable legal authorization to work on the grounds after 6:00 p.m. The municipal secretary contacted Jefferson personally with two possible alternatives: relocation to the Popular Shopping Center or removal from the downtown streets without any compensation. 
As unregistered street hawkers, Jefferson and his colleagues were subject to random inspections by the Secretariat of Economic Development and to surveillance organized through the local chamber of commerce. A palpable sense of inevitability regarding relocation was pervasive given the launching of a larger downtown revitalization project called "Viva Centro!," which was requested and partially financed by the Porto Alegre Chamber of Commerce and the formal union of shopkeepers. Owing to the lack of political support for unregistered street hawkers who wanted permanent permits to trade at Rua da Praia, Jefferson opted to defend the construction of the Popular Shopping Center as a PB demand. The 120 street hawkers that he represented at Rua da Praia arrived en masse at PB meetings in support of the project.

Jefferson's speech at the COP on July 2006 illustrates the insertion of this public-private partnership project into the $\mathrm{PB}$ :

On July 9th we gave the mayor a T-shirt like this one, which says "Camelódromo right now!" Our association supports this project. However, there is a movement sponsored by the Porto Alegre's bourgeoisie that disapproves of the Camelódromo project because they do not want us to work in a respectful environment in which we can compete against them on an equal basis for clients. I would like to say that the Camelódromo does not belong to Rua da Praia, Plaza XV, or to any other camelôs. The Camelódromo belongs to the delegates and councilors of the $\mathrm{PB}$, particularly the delegates from the downtown region. The delegates from my region came up with the Camelódromo idea. This movement sponsored by the bourgeoisie opposes this idea because they are against equal working conditions. Thank you!

Such bourgeoisie-against-workers discourse was typical of Jefferson. He had unsuccessfully run for a city council seat as a member of the Communist Party of Brazil in 2008 and for a state congress seat as a member of the Socialist Party of Unified Workers 2 years later. Only a few PB councilors were ever able to transition from elected positions in participatory democracy to elected seats in representative democracy. Jefferson's political aspirations may have informed his eagerness to embrace and take credit for the Camelódromo project.

Furthermore, Jefferson's fears of organized opposition and chamber of commerce retaliation against the Camelódromo were not entirely unfounded. Indeed, a small segment of the chamber of commerce opposed any proposal that allowed streets hawkers to work in the downtown area, even if they were relegated to one building in the historical center's periphery. However, the eagerness of small and large retailers alike to clean the streets of what they described as the nuisance of street hawking prevailed. By July 2006, some 18 months after Mayor Fogaça took office, it seemed that all stakeholders had reached a consensus on the benefits of the enterprise. Even Alberto, who fought against the Popular Shopping Center by speaking out against the mayor's proposal at PB meetings (personal interview, November 7, 2009), made partial claims of authorship for the original idea of a new Camelódromo in the current location:

Ana Paula Pimentel Walker: So the Camelódromo was a 2005 demand of the Economic Development Thematic Forum?

Alberto: Yes, during my first term in the PB in which I was a delegate, not councilor. It was a demand of the Association of Street Hawkers of Plaza XV. We asked for two central aisles in the Rui Barbosa Plaza [the place where the Popular Shopping Center was eventually built]. Our intention was not to discriminate [against camelôs not from the Plaza XV]; we were only taking care of that sector because Plaza XV was too crowded. So my main idea for the Camelódromo demand was to create another area to help relieve 
the crowding of stallholders at Plaza XV, which was too crowded. Our work there was almost subhuman. ... From the time the demand was recorded in the PB, the government began to look carefully at the site in order to organize the placement all 800 camelôs in here. However, there aren't 800 camelôs [from Plaza $\mathrm{XV}$. Since the beginning I was opposed to having 800 street hawkers in one place; I always found this overcentralization very problematic for doing business. And so I say again that we need some adjustments. Likewise I say again that the construction of the Camelódromo was a PB demand, but we did not demand that it be built the way it is now. And no one could say that this construction, the way it was built, was a demand of the PB, because private money has been invested in this public space.

Therefore Alberto did not envision an enclosed working-class shopping center to house all downtown street hawkers. He did, however, envision a Camelódromo complementary to the current one on Plaza XV, with more infrastructure, such as a roof. Alberto and Jefferson's dispute over the original demands for the Camelódromo can probably best be understood as a dispute over status, the kind of status that can later be translated into political power. Politicians were also involved in competing claims to the authorship of the Popular Shopping Center; Mayor Fogaça and the municipal secretary of economic development, Idenir Cechhin, both claimed credit for improving the walkability and neatness of downtown streets and helping to regularize the informal trade of Porto Alegre. ${ }^{9}$

Via a bidding process, the municipality selected Verdicon Construções to build the marketplace and manage the stores. The developer, with headquarters in Porto Alegre, specialized in building prisons, having built more than 50 in seven Brazilian states. The Popular Shopping Center was its first public-private partnership and the first nonprison contract. Verdicon affirms that the initiative for the public-private partnership came from the municipality (Verdicon, 2013). Verdicon is building similar malls to house former street hawkers in neighboring cities; in fact, the developer opened its second mall of this kind in December 2012 in Pelotas.

By the time I arrived in Porto Alegre in 2009, it was an open secret that Alberto had offered his support to the municipal government for the Popular Shopping Center project in exchange for the best locations in the new Camelódromo for himself and his followers. The project was divided into sectors A and B and had some stalls located in prime selling spots (Figure 2).

Sector A, facing the busy Voluntários da Pátria Street, afforded the best sales spaces as these stalls were conveniently accessible to people hunting for bargains at the traditional low-cost shops of Voluntários da Patria. Similarly, sector A was accessible to the street by escalators, which made these stalls even more attractive. Meanwhile, sector B, facing the pedestrian-unfriendly Mauá Avenue, has no access to a main entrance and is separated from sector A by a skywalk. Thus a controversy developed regarding the procedures that would be adopted to allocate the stalls to different groups of street hawkers.

Jefferson, who was from the Stallholders of Rua da Praia, not only formed alliances with similar groups of stallholders but also advocated a lottery system as the fairest procedure. Alternatively, Alberto claimed that seniority in street selling should count more than any other formula. The seniority procedure would give Plaza XV's camelôs the right to select their preferred locations. Nonetheless, this debate was immaterial. By the time a newspaper article in the widely circulated periodical Zero Hora exposed the conflict, the agreement had already been reached. Alberto had agreed to peacefully relocate to the Popular Shopping Center after he was given the first choice of prime selling spots. This strategic consent resulted from multiple meetings over the course of several months, during which elected officials and Alberto gradually became willing to compromise. 


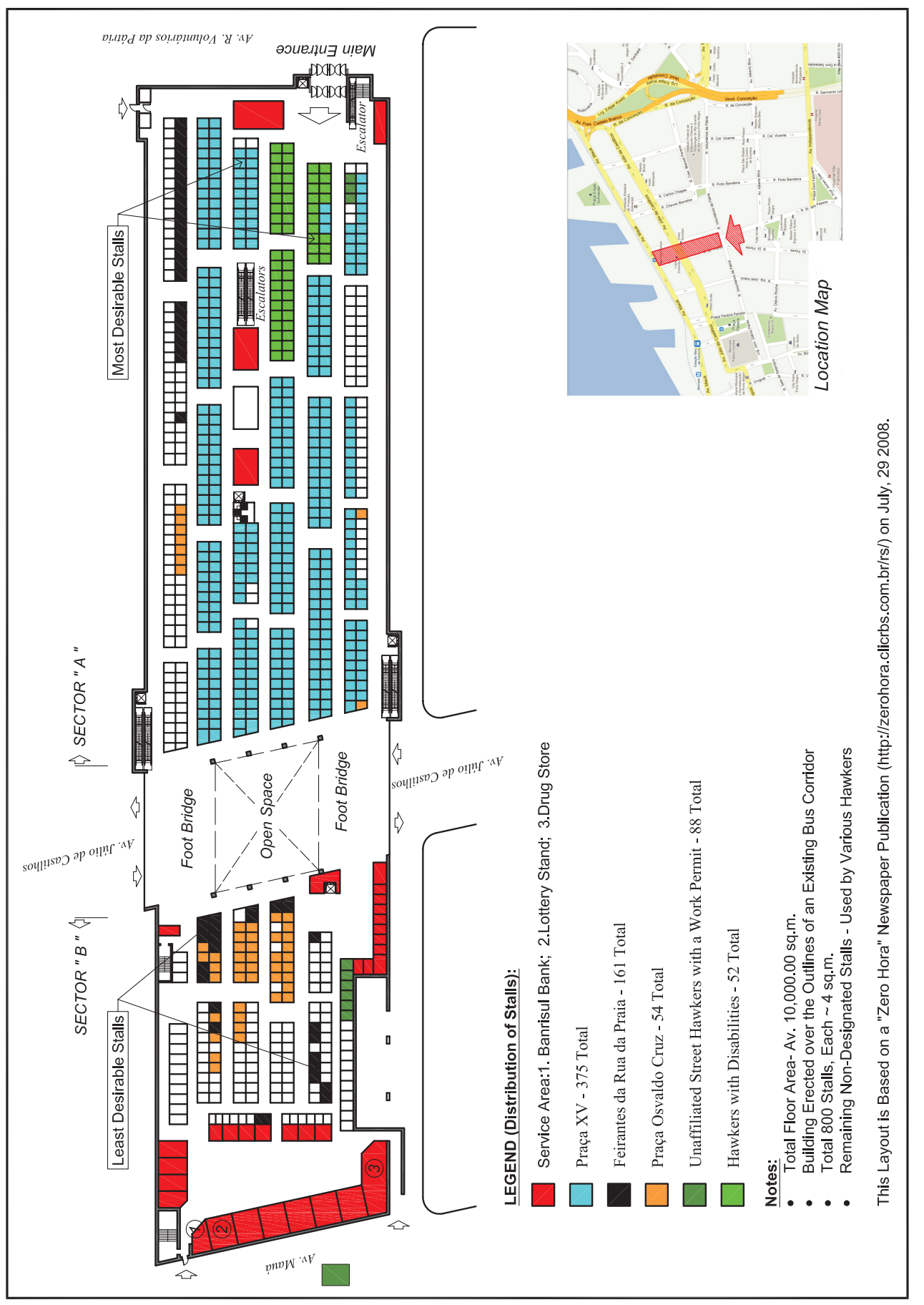

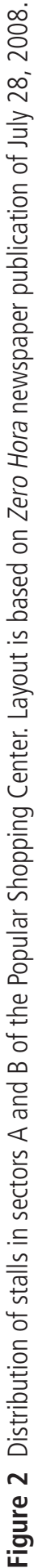


The symbolic insertion of the Popular Shopping Center, a public-private partnership, into the discursive arena of the PB meetings was made possible by a leadership strategy that F. G. Bailey (2001, p. 33) called "brokered consensus." In contrast to direct consensus, which is characterized by a uniformity of opinions and goals, brokered consensus relies on a pluralism of goals and interests. According to Bailey (2001, p. 33), if direct consensus relies on issues, brokered consensus

requires a leader who knows how to put deals together and make a sufficient number of people obligated enough to cooperate in doing what he wants done. That he has an agenda of this kind distinguishes a leader from a mere broker, who takes his profit in a material rather than a political form.

The strategies employed by the elected officials to achieve brokered consensus were individually tailored to each street hawker leader. For Jefferson, the strategies consisted of a mix of direct threats to leaders, such as eviction without compensation, and psychological manipulation through stroking, a technique that made them feel included in the project's vanguard (Bailey, 2001, p. 136). In contrast, Alberto's strategy consisted of pure political bartering. In many ways, stroking did not match Alberto's personality because he had no real political aspirations; he saw himself only as a businessman protecting his interests.

\section{The outcomes of the Popular Shopping Center: Winners, losers, and in-betweens}

International development organizations celebrate public-private partnerships as a viable alternative to the delivery of services for the urban poor in developing countries. Nevertheless, it is uncommon to evaluate these public - private partnerships on equity criteria (Miraftab, 2004). In this section, I analyze the fairness of the Camelódromo project for the three groups involved: the municipal government that conceded the public property; various civil society organizations affected by the project at different levels, such as street hawkers' associations and the chamber of commerce; and the developer, Verdicon Construções, which fulfilled the role of the private investor in this public-private partnership.

Verdicon Construções S/A, selected through a bidding process, claims to have invested R \$25 million (US\$14.7 million) in the project. In exchange, the developer acquired a 25-year contract to manage the Popular Shopping Center, which was built on public property. Based on interviews with civil servants and bureaucrats, I estimate that the developer receives R $\$ 5$ million (US $\$ 2.9$ million) in annual revenue from the stall rentals and management fees from stallholders. Such investment is extremely profitable, despite the expenses of maintenance, security, and advertisement.

To maximize profit, Verdicon also changed the project's design to the detriment of street hawkers. Mayor Fogaça's proposed study plan had sophisticated features, including a glass hemispherical roof and multiple well-finished openings in the laterals. The proposed doors in the laterals might have increased consumer flux in sector B, which faces the pedestrian-unfriendly Mauá Avenue. Verdicon's final design, however, dropped many of the features that would have made the space more functional for the street hawkers. According to vendors and bloggers, the final plan resembled the architecture of a prison more than a mall (see Figures 3 and 4); in fact, it used the same large concrete blocks used for building prisons. Street hawkers complain that despite the high rent and management fees, the building does not have an adequate cooling system and that, on hot summer days, customers avoid the place.

Nevertheless, the approximately 400 street hawkers who came from Plaza XV, mostly in section A, have reported modest profit increases since the relocation. Weekly stall rentals in the Popular Shopping 


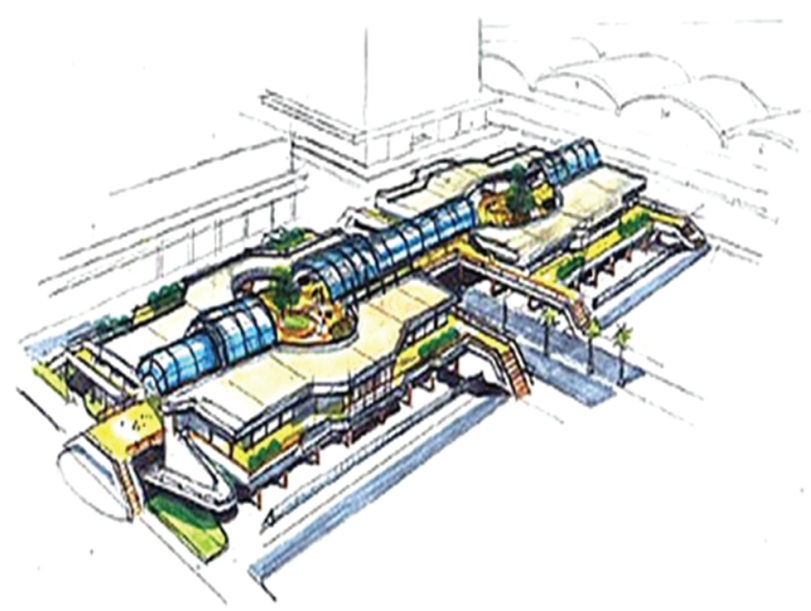

Figure 3 Study project of the Popular Shopping Center produced by the executive branch. From the blog Porto Imagem, May 25, 2011, http://portoimagem.wordpress.com/2011/05/ 29/projeto-original-x-real-\%e2\%80\%93parte-2/.

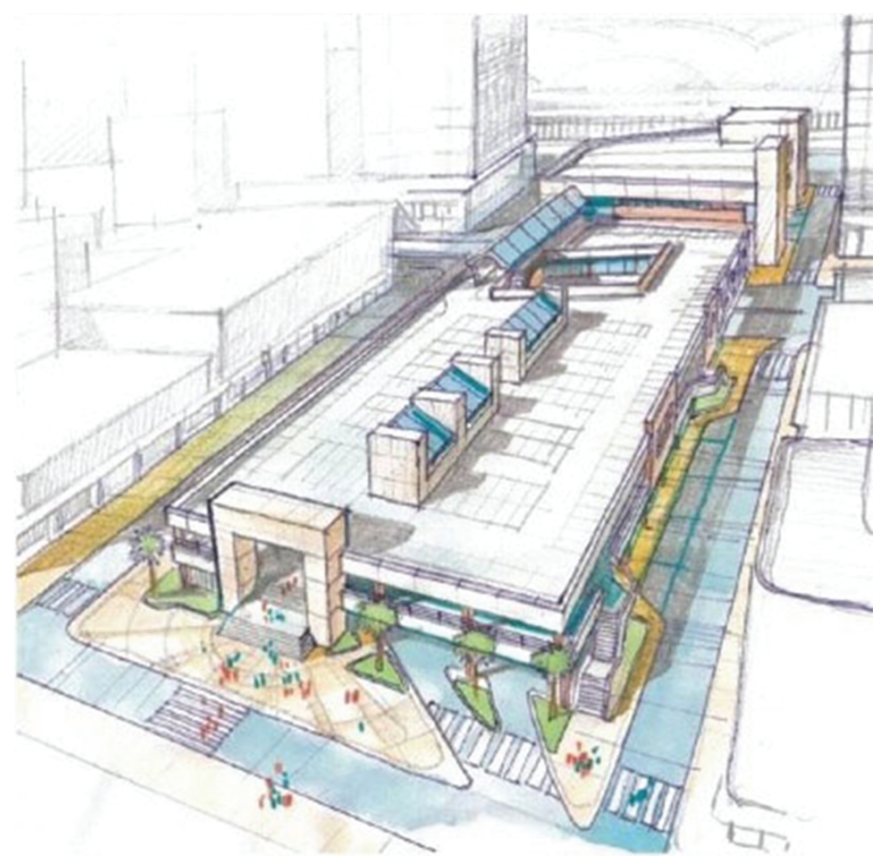

Figure 4 Layout built by developer. From the blog Porto Imagem, October 29, 2008, http://portoimagem.word press.com/2008/10/29/camelodromocomeca-a-funcionar-somente-emjaneiro-2009/.

Center go for R $\$ 25$ (US\$14.70) per square meter, with the average stall size standing at four square meters. The management fees amount to the equivalent of one week's rent. Therefore the bare minimum cost for a stall in the Camelódromo averages R \$500 (US\$294) per month. Although these expenses are too high for some vendors, the Plaza XV street hawkers were already used to having fixed monthly expenses.

The streets are not cost-free for most street hawkers. At the very least, Plaza XV street hawkers had to pay for overnight storage of their tents. However, most street vendors hire a cavaleiros or carregadores (horseman, porter) to set up and break down their tents at Plaza XV's assigned spots. Informants told me that Plaza XV monthly expenses averaged around R\$300 (US\$176). Relocation did not affect the working hours of Plaza XV street hawkers because these workers already had regular daylight schedules, unlike most unregistered street hawkers of Rua da Praia, who started working after 6:00 p.m., after the 


\section{A. P. Pimentel Walker}

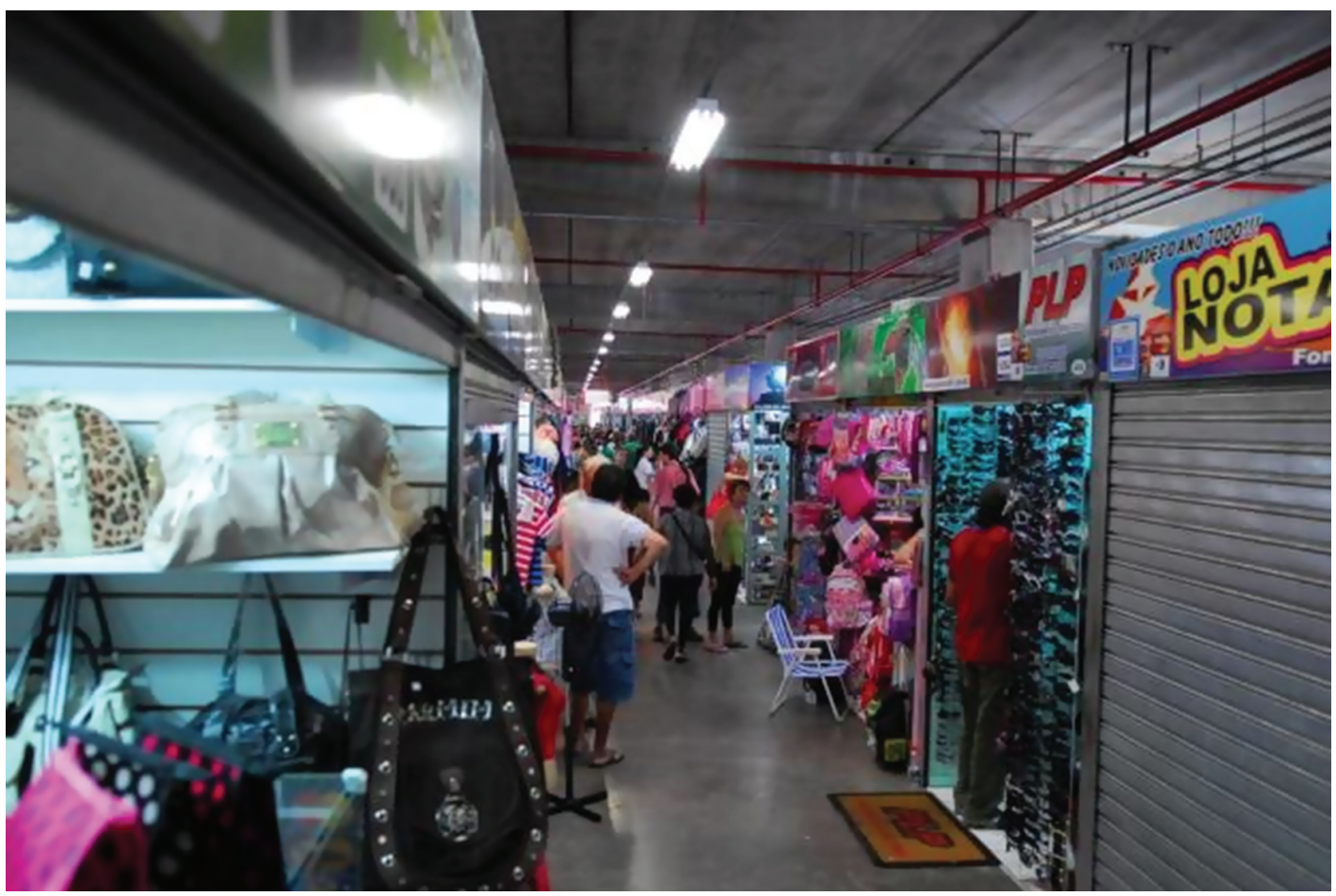

Figure 5 Stalls in the Popular Shopping Center. From Diário Gaúcho newspaper, May 24, 2013. Photo by Andréia Graiz. Available online at http://diariogaucho.clicrbs.com.br/rs/dia-a-dia/noticia/2013/05/negociacaodas-bancas-do-camelodromo-inflacionou-4148191.html.

shops closed. The most significant gains reported by former Plaza XV and other relocated street hawkers are improvements to the workplace, such as shelter from weather, that help preserve workers' personal health and merchandise (Figure 5).

Despite these improvements, the situation for most current sector B stallholders is much more daunting. A lack of sales and clientele has rendered them extremely indebted and unable to pay rent and management fees to Verdicon Construções. An additional expense corresponds with the new credit card machines that street hawkers use to cater to the increasing number of low-income consumers who shop with this mode of payment. Brazilian consumers classified based on purchasing power as belonging to classes C and D now have increased access to credit cards (Scalco \& Pinheiro Machado, 2010, p. 329). In Brazil, credit card companies such as Visa and MasterCard process charges in installments. For instance, a client in the Camelódromo may spend R\$60 (US\$35.30) and pay with his card in three installments of R $\$ 20$ (US\$9.30). Owing to its close proximity to the low-cost shops of Voluntários da Patria that provide installment sales through credit cards, street hawkers signed contracts with credit card companies hoping to remain competitive.

Whatever increases in sales they accrued were not adequately compensated given the added expenses of rent, management, and credit card services. Most vendors are unable to pay back the credit card companies. Some street hawkers have resorted to using informal moneylenders to pay their formal obligations. Such situations quickly became unsustainable, and about $5 \%$ of the street hawkers, mostly those working in sector B, have defaulted and been evicted from Wharfs Mall. 
The evictions produced headlines in the major local newspapers and resulted in several meetings of the PB with the head of the LSG secretariat and delegates from the downtown district and Thematic Forum for Economic Development, Taxation, Tourism, and Labor. The disagreements I witnessed during many of the deliberations centered on the nature of the Camelódromo project. On one hand, Jefferson argued that the Camelódromo was a social project to promote the welfare of street hawkers in the city. On the other hand, Alberto explained the business character of public-private partnerships. In his words, the Camelódromo may have addressed a social problem, but the goal was always profit, not only for the developer, but also for street hawkers. Thus, as in any competitive business, he concludes, some will prosper while others will inevitably fail.

This assessment of winner and losers would not be complete without some mention of the reaction of Porto Alegre's formal retailers, who have always expressed their displeasure with street hawking and have lobbied politicians to take action against such informal commerce. To celebrate what they frame as the cleansing of street hawking from the downtown streets, right after the grand opening inauguration of the Popular Shopping Center, representatives from the Union of Shopkeepers and the Porto Alegre Chamber of Commerce held a festive march through the empty streets that had once been filled with stallholders and their clients.

In the long-standing battle between street hawkers and the formal business owners over the use of public space in Porto Alegre, standards for orderly and clean sidewalks and roads justify plans for downtown redevelopment that exclude street vendors. The articles by Robert Rotenberg and Denise Lawrence-Zúñiga in this volume reveal the political economy of space planning and design manifested through aesthetic preferences and standards. As Rotenberg's article highlights, newly elected politicians reshape planning practice to better suit the aesthetic preferences and economic interests of their constituencies.

\section{Conclusion}

I investigated the circumstances under which the redistributive achievements of counterhegemonic forms of urbanization and globalization, such as the $\mathrm{PB}$ of Porto Alegre, become partially reversible. Broadly, the article highlights the vulnerability of participatory planning institutions to partisan politics and market forces. In Brazil, the transition from strong government regulation to a free-market economy and from military regimes to electoral democracy sparked a nationwide interest in participatory city planning as a tool to deepen democracy and redistribute local resources. Participatory budgets and local leftist political governments thrived in the 1990s, providing a cushioning for the urban poor against rising unemployment and cuts on social spending. All through the 1990s in Porto Alegre, politicians, social movements, and planners attempted to manage profit-led neoliberal urbanization via participatory budgeting. The proliferation of leftist city governments and participatory budgets in the rest of Brazil fostered the progressive coalition that elected President Lula in the 2002 national elections.

However, municipal budgets are connected to global financial markets. Owing to the 2002 South American economic crisis, Porto Alegre went from a budget surplus of $4 \%$ in 2001 to a deficit of $4 \%$ in 2004. Simultaneously, Brazil underwent moderate fiscal recentralization, which diminished tax transfers to municipalities. Together these factors diminished the capacity of the municipal government to implement PB-elected demands. Although the stalled PB demands contributed to the failure of the Workers' Party to obtain a fifth term in office, they did not debunk the PB as an urban planning mechanism. 
Neoliberal restructuring projects have produced uneven and heterogeneous patterns of development that significantly affect the political economy of cities, nations, and world regions (Brenner et al., 2010). As this article demonstrates, it is important to understand how municipal responses to neoliberal policies at the national and global levels have modified neoliberalism. In particular, I argue that social classes with an investment in the urban question are key actors in developing hybrid models of neoliberal urbanization. These hybrid models not only encompass local policies for economic development, such as public-private partnerships, but also sophisticated ideologies about the role of government and governance in urban development.

In the case of neoliberal Porto Alegre, the executive branch of the municipal government, in collaboration with UNESCO, crafted an ideology of the state that was neither an ideology of the minimum state nor an ideology of the developmentalist state. The philosophy of LSG envisioned the municipal government as an articulator and reference in a network of connections: the state as an actor of neither greater nor lesser significance than business, citizens, NGOs, and other actors. This state ideology was strategically crafted by the "A Better City, a Better Future" coalition to combat the ideology of the $\mathrm{PB}$, in which the municipal government has the responsibility to provide public works and services. As Goldfrank (2003) shows, political parties that opposed the Workers' Party did not initially have an ideology of participatory democracy and development. Therefore I argue that the path of the Camelódromo project from public-private partnership to the PB reveals not the perverse confluence of leftist and neoliberal participatory projects, as some scholars argue (e.g., Dagnino, 2003, p. 7), but the strategic co-optation of the former by the latter. Porto Alegre's right-wing political parties did not have a vision of participatory democracy to start with and then later embraced the leftist participatory project. Instead, center-right politicians in Porto Alegre were politically forced to envision a strategy of participatory planning that could incorporate, or at least manage and contain, the outcomes of municipal socialism through popular participation characteristic of the PB. What this article described was not the normative ideology of the state; instead, we observed the strategic manufacturing and use of ideology by the state, embodied in the LSG program. The capacity of city planning mechanisms to restrain neoliberal urbanization, or at least to better redistribute its surpluses spatially, rests not only on the development of the liberalized economy but also on the class struggles on the ground.

\section{Notes}

1 The term right to the city was popularized by Henri Lefebvre (1968[1996]). Contemporary manifestations of the right to the city movement are found in in both developed and developing countries (see, e.g., Souza, 2009; Harvey, 2012).

2 I assess the changes in the amounts and patterns of resource allocation for social housing before and after that in Pimentel Walker (2013b).

3 Dissertation research was funded by the National Science Foundation (award 0922573) and the Foundation for Urban and Regional Studies. I translated interview quotations, speech quotations, and excerpts from propaganda material. Pseudonyms are used for the street hawkers' representatives, although I had their permission to use their real names.

4 There is an extensive anthropological and planning literature on informal trade. The planning literature is divided between scholars (e.g., Moser, 1978) who see street hawkers as workers marginalized by international capital versus scholars and organizations (e.g., the International Labour Organization) that see street hawkers as entrepreneurs at the forefront of economic development. For a fuller account of street hawkers' lives and trade in Porto Alegre, see Kopper (2012) and Pinheiro Machado (2004).

5 The $8 \%$ figure is based on the estimated 100 thousand Porto Alegre residents involved in budgetary deliberations. This estimate comes from approximately one thousand formal and informal civil society organizations that register with the PB at the yearly Assemblies. These organizations have internal meetings and networks to deliberate about the budgetary demands and monitor their implementation. Attendance at 23 regional and thematic assemblies of the PB ranged from 11 thousand to 14 thousand residents between 1996 and 2001 (UNESCO, 2001; Fedozzi et al., 2009). 
6 The exchange rate I use is US\$1.00=R\$1.7 (Brazilian reais), based on the exchange rates for October 29, 2010.

7 The legality of the Participatory Budget rests on the formal delegation of some statutory powers, related to budget preparation, from the Executive Branch to the people. The mayor voluntarily initiates this delegation of authority. However, there is no similar delegation of authority from the City Council, which continues to hold the prerogatives of budget approval. There is an ongoing debate about the legality of the Participatory Budget in Brazil (Inter-American Development Bank, 2003 pp. 18-19).

8 The presence of the World Social Forum in Porto Alegre during its first few meetings also contributed to the self-image of Porto Alegre as the world capital of participatory democracy. I attended the 2003, 2005, and 2010 meetings of the World Social Forum in Porto Alegre and witnessed the testimony of several delegates and councilors who were invited to speak.

9 The demand that Alberto is referring to is in fact registered in the 2006 Investment Plan of the PB (demand 2006660, "Construction of a Popular Shopping Center") as a demand originated by the PB's Thematic Forum for Economic Development, Taxation, Tourism, and Labor rather than being a Downtown district PB demand.

\section{References}

Abers, R. N. (1998). From clientelism to cooperation: Local government, participatory policy, and civic organizing in Porto Alegre, Brazil. Politics and Society, 26(4), 511-537.

Bailey, F. G. (2001). Treasons, stratagems, and spoils: How leaders make practical use of values and beliefs. Boulder, CO: Westview Press. Baiocchi, G. (2003). Participation, activism and politics: The Porto Alegre experiment. In A. Fung \& E. O. Wright (Eds.), Deepening democracy: Institutional innovations in empowered participatory governance (pp. 45-76). London, England: Verso Books.

Baiocchi, G. (2005). Militants and citizens: The politics of participatory democracy in Porto Alegre. Stanford, CA: Stanford University Press.

Beard, V. A., Miraftab, F., \& Silver, C. (Eds.) (2008). Introduction: Decentralized planning in the global south. In Planning and decentralization: Contested space for public action in the global south (pp. 1-18). New York, NY: Routledge.

Brenner, N., Peck, J., \& Theodore, N. (2010). After neoliberalism? Globalizations, 7(3), 327-345.

Caldeira, T., \& Holston, J. (2005). State and urban space in Brazil: From modernist planning to democratic interventions. In A. Ong \& S. J. Collier (Eds.), Global anthropology: Technology, governmentality, ethics (pp. 393-416). London, England: Blackwell.

Camarano, M., \& Fraga, C. (2003). o Comércio Fora da Lei [Trade outside the law]. Revista Extra Classe! 8(73). Retrieved from http://www.sinprors.org.br/extraclasse/jul03/movimento.asp.

Campbell, T. (2003). Quiet revolution: Decentralization and the rise of political participation in Latin American cities. Pittsburgh, PA: University of Pittsburgh Press.

Cassen, B. (1998). Brazil's new experiment: Participative democracy in Porto Alegre. Le Monde Diplomatic, English edition. Retrieved from http://mondediplo.com/1998/10/08brazil.

Dagnino, E. (2003). Citizenship in Latin America: An introduction. Latin American Perspectives, 30(2), 3-17.

Dickovick, J. T. (2007). Municipalization as Central Government strategy: Central-Regional-Local Politics in Peru, Brazil, and South Africa. Publius: The Journal of Federalism, 37(1), 1-25.

Elinoff, E. (2012). Smouldering aspirations: Burning buildings and the politics of belonging in contemporary Isan. South East Asia Research, 20(3), 381-398.

Fedozzi, L. (2001). Orçamento Participativo: Reflexões sobre a Experiência de Porto Alegre (3rd ed.). Porto Alegre, Brazil: Tomo Editorial. Fedozzi, L., Furtado, A., Macedo, C. E. G., Parenza, C., \& Bassani, V. D. S. (2009). Observando o Orçamento Participativo de Porto Alegre. Perfil Social e Associativo Avaliação, Formação de uma Cultura Política e Democrática e Possíveis Inovações. Porto Alegre, Brazil: Observa POA e Prefeitura de Porto Alegre.

Feitosa, F. F., Camara, G., Monteiro, A. M. V., Koschitzki, T., \& Silva, M. P. S. (2007). Global and local spatial indices of urban segregation. International Journal of Geographical Information Science, 21(3), 299-323.

Goldfrank, B. (2003). Making participation work in Porto Alegre. In G. Baiocchi (Ed.), Radicals in power: The worker's party (PT) and experiments in urban democracy in Brazil (pp. 27-52). London, England: Zed Books.

Goldsmith, W., \& Vainer, C. (2001). Participatory budgeting and power politics in Porto Alegre. Land Lines, 13(1), 115-119.

Goodale, M., \& Postero, N. (2013). Neoliberalism, interrupted: Social change and contested governance in contemporary Latin America. Stanford, CA: Stanford University Press.

Green, D. (2003). Silent revolution: The rise and crisis of market economies in Latin America. New York, NY: Monthly Review Press. Hackworth, J. (2007). The Neoliberal city: Governance, ideology, and development in American urbanism. Ithaca, NY: Cornell University Press. Harvey, D. (1989). From managerialism to entrepreneurialism: The transformation in urban governance in Late Capitalism. Geografiska Annaler, Series B: Human Geography, 71(1), 3-17. 
Harvey, D. (2012). Rebel cities: From the right to the city to the urban revolution. London, England: Verso Books.

Heller, P. (2001). Moving the state: The politics of democratic decentralization in Kerala, South Africa, and Porto Alegre. Politics and Society,

29(1), 131-163.

Inter-American Development Bank. (2003). Assessment of participatory budgeting in Brazil. Cambridge, MA: Center for Urban Development

Studies Graduate School of Design, Harvard University.

Isham, J., \& Kähkönen, S. (2003). The importance of "exit and voice" in the provision of clean water: Evidence from India and Sri Lanka.

In S. Ramaswamy \& J. W. Cason (Eds.), Development and democracy: New perspectives on an old debate (pp. 98-122). Lebanon, NH:

University Press of New England.

Kohl, B. (2003). Democratizing decentralization in Bolivia: The law of popular participation. Journal of Planning Education and Research,

23(2), 153-164.

Kopper, M. (2012). De Camelôs a Lojistas: Etnografia da Transição do Mercado de Rua para um Shopping Popular em Porto Alegre-RS

(M.A. thesis). Department of Anthropology, Federal University of Rio Grande do Sul.

Lefebvre, H. 1968(1996). The right to the city. In E. Kofman \& E. Lebas (Eds. \& Trans.), Writings on cities (pp. 63-183). Oxford, England:

Blackwell.

Lüchmann, L. (2008). Participação e Representação nos Conselhos Gestores e no Orçamento Participativo Caderno. CRH, 21(52), 87-97.

Marquetti, A. (2003). Participação e Redistribuição: 0 Orçamento Participativo em Porto Alegre. In L. Avritzer \& Z. Navarro (Eds.), A Inovação

Democrática no Brasil (pp. 129-156). São Paulo, Brazil: Cortez Editora.

Miraftab, F. (2004). Public-Private partnerships: The Trojan horse of neoliberal development? Journal of Planning Education and Research,

24(1), 89-101.

Moser, C. O. N. (1978). Informal sector or petty commodity production: Dualism or dependence in urban development? World Development,

6(9-10), 1041-1064.

Perreault, T., \& Martin, P. (2005). Geographies of neoliberalism in Latin America. Environment and Planning, 37, 191-201.

Pimentel Walker, A. P. (2013a). Embodied identity and political participation: Squatters' engagement in the participatory budget in Brazil.

Ethos, 41(2), 199-222.

Pimentel Walker, A. P. (2013b). Workers' party in face-to-face citizenship: The effects, ethics, and aesthetics of participatory planning in Brazil

(Ph.D. dissertation). Department of Anthropology, University of California, San Diego.

Pinheiro Machado, R. (2004). A Garantia Soy Yo: Etnografia das Práticas Comerciais entre Camelôs e Sacoleiros na Cidade de Porto Alegre e

na Fronteira Brasil/Paraguai (Unpublished M.A. thesis). Department of Anthropology, Federal University of Rio Grande do Sul.

Portes, A., \& Roberts, B. R. (2005). The free-market city: Latin American urbanization in the years of the neoliberal experiment. Studies in

Comparative International Development, 40(1), 43-82.

Prefeitura de Porto Alegre and UNESCO. (2006). Governança Solidária [Local DVD]. Curitiba, Brazil: lesde Brasil S.A.

Roever, S. (2010). Street trade in Latin America: Demographic trends, legal issues, and vending organizations in six cities. In S. K. Bhowmik

(Ed.), Street vendors in a global urban economy (pp. 208-240). New York, NY: Routledge.

Rolnik, R. (2011). Democracy on the edge: Limits and possibilities in the implementation of an urban reform agenda in Brazil. International

Journal of Urban and Regional Research, 35(2), 239-255.

Santos, B. S. (2005). Participatory budgeting in Porto Alegre: Towards a redistributive democracy. In B. S. Santos (Ed.), Democratizing

democracy: Beyond the liberal democratic canon (pp. 307-405). London, England: Verso Books.

Santos, M. (2007). 0 Espaço Cidadão. In Coleção Milton Santos (Vol. 8). São Paulo, Brazil: Edusp, Editora da Universidade de São Paulo.

Scalco, L. M., \& Machado, R. P. (2010). Os Sentidos do Real e do Falso: o Consumo Popular em Perspectiva Etnográfica. Revista de

Antropologia, 53(1), 322-359.

Soja, E. (2010). Seeking spatial justice. Minneapolis: University of Minnesota Press.

Tendler, J. (2000). The economic wars between the states. Paper prepared under the auspices of the department of urban, Studies/Bank of

the Northeast Project, MIT.

UNESCO. (2001). MOST Clearinghouse Database. Best Practices: The Experience of the Participative Budget in Porto Alegre, Brazil. UNESCO

Management of Social Transformations Programme. Retrieved from http://www.unesco.org/most/southa13.htm.

Verdicon Construções. (2013). Verdicon Construções. Retrieved from http://www.vsisbrasil.com.br/. 